\title{
Perbandingan kinerja metode C4.5 dan Naive Bayes dalam klasifikasi artikel jurnal PGSD berdasarkan mata pelajaran
}

\author{
Utomo Pujianto1, Putri Yuni Ristanti² \\ 1. Universitas Negeri Malang, Indonesia | utomo.pujianto.ft@um.ac.id \\ 2. Universitas Negeri Malang, Indonesia | putriyuni7@gmail.com
}

\begin{abstract}
Abstrak
Pendidikan mempunyai standar sebagai acuan dalam proses pembelajaran. Dalam hal ini Pemerintah telah mengatur standar pendidikan di Indonesia, mengacu pada Peraturan Pemerintah Republik Indonesia Nomor 19 Tahun 2005 Pasal 6 ayat (1) yaitu kurikulum untuk jenis pendidikan umum, kejuruan, dan khusus pada jenjang pendidikan dasar dan menengah. Sesuai dengan Peraturan Pemerintah tersebut, ditetapkannya Peraturan Menteri Pendidikan Nasional Republik Indonesia Nomor 23 Tahun 2006 pasal 1 ayat (2), tentang Standar Kompetensi Lulusan yang diantaranya memuat SK-KMP (Standar Kompetensi Kelompok Mata Pelajaran). Standar inilah yang dijadikan sebuah rujukan untuk tenaga pendidik, dan bakal tenaga pendidik khususnya mahasiswa bidang pendidikan untuk membuat sebuah media pembelajaran, jurnal sebagai bahan ajaran yang pokok. Tujuan penelitian ini untuk mengklasifikasikan minat mahasiswa PGSD terhadap tema mata pelajaran menurut SK-KMP menggunakan metode Naive Bayes dan Decision tree J48. Hasil penelitian tersebut dapat dijadikan sebagai referensi untuk pengambilan tema pada mata pelajaran di tahun mendatang untuk lebih bervariasi, tidak hanya membahas tentang salah satu mata pelajaran tersebut. Kinerja dari kedua metode tersebut akan dibandingkan, sehingga dapat diketahui kinerja metode mana yang lebih baik dalam melakukan klasifikasi dokumen. Pengujian performa algoritma klasifikasi yang digunakan adalah teknik K-fold Cross Validation. Berdasarkan pengujian performa penerapan algoritma Naïve Bayes dan Decision Tree $\mathrm{J48}$ menggunakan teknik K-Fold Cross Validation terhadap 200 judul dan abstrak artikel jurnal, didapatkan algoritma Naive Bayes, tingkat akurasi sebesar $84 \%$. Sementara itu, untuk hasil yang diperoleh dengan algoritma Decision Tree J48, tingkat akurasi sebesar $86 \%$.
\end{abstract}

\section{Kata Kunci}

Klasifikasi, SK-KMP, PGSD, Naive Bayes, Decision Tree J48, Weka

TEKNO Vol. 29 Issue 1, p50-67| Jurusan Teknik Elektro, Universitas Negeri Malang, Indonesia | Maret 2019 U. Pujianto, Putri Yuni Ristanti | Perbandingan kinerja metode C4.5 dan Naive Bayes dalam klasifikasi ... 


\section{TEKNO Jumal Teknologi, Eektro, dan Kejiruan}

http://journal2.um.ac.id/index.php/tekno | ISSN 1693-8739

\section{Pendahuluan}

Kumpulan Jurnal yang terdapat didalam web Universitas kebanyakan hanya di urutkan berdasarkan volume dan tahun pembuatan jurnal. Dengan penataan konsep yang seperti ini, mahasiswa yang mencari tipe jurnal yang diinginkan, akan membuka satu persatu jurnal berdasarkan volume dan tahun, tentu hal ini sangat tidak efisien untuk mahasiswa. Penelitian ini memfokuskan kepada mahasiswa program studi PGSD untuk memudahkan pencarian jurnal berdasarkan SK-KMP untuk pengambilan tema pada mata pelajaran. Dengan Penelitian ini keuntungan yang didapatkan akan membantu mahasiswa prodi PGSD untuk dapat mendapatkan tipe jurnal berdasarkan mata pelajaran dengan sangat efisien dan pengambilan judul pada tahun depan untuk dapat lebih bervariasi, tidak hanya membahas tentang salah satu mata pelajaran. Konsep ini tidak merubah konsep penataan awal jurnal, tetapi melengkapinya dengan penambahkan fungsi klasifikasi. Ketika mahasiswa ingin mencari jurnal tetap merujuk pada volume dan tahun pembuatan, kumpulan jurnal yang ada didalam volume akan diklasifikasikan berdasarkan SK-KMP. Penelitian ini bertujuan untuk membandingkan kinerja algoritma Naive Bayes dan Decision Tree J48 pada klasifikasi jurnal PGSD.

Dengan berbagai informasi tersebut, informasi dapat diolah menggunakan sistem Information Retrieval dengan tujuan menemukan dokumen yang sesuai dengan kebutuhan seorang pengguna dengan lebih efisien. Dalam proses ini melibatkan tahap intermediate yaitu penyaringan, pencarian, operasi pencocokan data, dan peringkat (Huang et al., 2017).

Beberapa penelitian dilakukan dengan menggunakan metode klasifikasi untuk mendapatkan sebuah informasi atau pengetahuan dari dataset tentang pendidikan, yaitu klasifikasi ke dalam kategori berdasarkan kualifikasi Pendidikan dengan menggunakan algoritma naive bayes memiliki akurasi 90\% (Karthika \& Sairam, 2015). Klasifikasi teks pada data siswa menggunakan algoritma naïve bayes dengan akurasi $66,7 \%$ dan KKN dengan akurasi $38.89 \%$ (Rajeswari \& Juliet, 2017), klasifikasi menggunakan Decision Tree J48 Breast Cancer dengan akurasi $95 \%$ (Song \& Woo, 2015). Penelitian ini hanya menggunakan satu data set yaitu jurnal PGSD, dalam penelitian ini akan dibandingkan kinerja dari metode naive bayes dan J48 dalam pengklasifikasian jurnal PGSD berdasarkan SK-KMP.

Dataset yang digunakan dalam penelitian ini berasal dari situs jurnal PGSD yang beralamat di http://journal.student.uny.ac.id/jurnal/baca/99. Atribut yang digunakan yaitu Volume dan tahun jurnal, Judul, dan Abstrak. Penelitian dilakukan dengan membandingkan algoritma Naive Bayes dan Decision Tree J48 untuk mengklasifikasi mata pelajaran berdasarkan SK-KMP. Hasil dari penelitian ini mahasiswa khususnya program studi PGSD dapat dijadikan sebagai referensi untuk pengambilan tema pada mata pelajaran di tahun mendatang untuk lebih bervariasi, tidak hanya membahas tentang salah satu mata pelajaran tersebut. Penelitian ini juga menghasilkan perbandingan kinerja dari masing-masing algoritma dengan melihat nilai accuracy, precision, dan recall

TEKNO Vol. 29 Issue 1, p50-67| Jurusan Teknik Elektro, Universitas Negeri Malang, Indonesia | Maret 2019 U. Pujianto, Putri Yuni Ristanti | Perbandingan kinerja metode C4.5 dan Naive Bayes dalam klasifikasi ... 


\section{TEKNO Jumal Teknologi, Eektro, dan Kejivruan}

http://journal2.um.ac.id/index.php/tekno | ISSN 1693-8739

\section{Metode}

Pada penelitian ini menggunakan 2 algoritma yaitu Naive Bayes dan Decision Tree J48 untuk mengklasifikasikan jurnal PGSD, kinerja kedua algoritma tersebut diukur berdasarkan accuracy, recall dan precision.

1. Algoritma Naïve Bayes

Metode Naive Bayes merupakan metode yang popular dalam klasifikasi, metode ini terkenal dengan prediksi probabilitas dari data yang disajikan. Naive Bayes menggunakan teorema bayes. Naive Bayes memiliki nama lain seperti idiot's Bayes, simple Bayes dan independence Bayes karena kemudahannya serta tidak membutuhkan proses iterasi yang kompleks (Ashari, Paryudi, \& Tjoa, 2013). Naive Bayes merupakan sebuah metode pengklasifikasian peluang sederhana dengan asumsi antar variabel penjelas saling bebas (independen) dengan menjumlahkan frekuensi dan kombinasi nilai dari dataset yang diberikan (Suyadi, Setyanto, \& Fattah, 2017). Keuntungan penggunaan Metode Naive Bayes hanya memerlukan data latih yang kecil untuk memperkirakan parameter mean dan varians dari variabel yang diperlukan untuk klasifikasi. Hal ini dikarenakan variabel independen yang diasumsikan hanya variabel untuk setiap kelas yang harus ditentukan, bukan seluruh matriks kovarians (Wahyuningtyas et al., 2015). Naive Bayes merupakan metode supervised document classification yang membutuhkan data training sebelum melakukan proses klasifikasi. Dalam prosesnya, Naive Bayes mengansumsikan ada tidaknya sebuah fitur pada suatu kelas tidak berhubungan denga ada tidaknya fitur lain di kelas lain. Dalam proses pelatihan, dokumen telah ditentukan kategorinya. Kemudian akan diproses untuk membentuk pengetahuan berupa nilai probabilitas pada setiap term (kata). Proses ini akan menghasilkan sebuah term (kata) pada setiap dokumen yang mengkarakteristikkan dokumen pada suatu kategori tertentu. Untuk menghitung probabilitas kategori dokumen dapat digunakan Pers. (1). sedangkan untuk menghitung setiap kata yang terdapat pada dokumen latih digunakan Pers. (2).

$$
p\left(c_{j}\right)=\frac{n\left(\text { doc }_{j}\right)}{n(\text { sampel })}
$$

Keterangan:

$\mathrm{p}\left(\mathrm{c}_{\mathrm{j}}\right) \quad$ : probabilitas dokumen kategori

$\mathrm{n}\left(\mathrm{doc}_{\mathrm{j}}\right) \quad$ : jumlah seluruh dokumen pada suatu kategori

$\mathrm{n}$ (sampel) : jumlah seluruh dokumen latih 


\section{TEKNO Jumal Teknologi, Eektro, dan Kejiruan}

http://journal2.um.ac.id/index.php/tekno | ISSN 1693-8739

$$
p\left(w_{i} \mid c_{j}\right)=\frac{1+n_{i}}{n+|x|}
$$

Pers. (2)

Keterangan:

$\mathrm{p}\left(\mathrm{w}_{\mathrm{i}} \mid \mathrm{c}_{\mathrm{j}}\right) \quad$ : probabilitas kata pada setiap kategori

ini $\quad$ : frekuensi kemunculan kata pada setiap kategori

$\mathrm{n} \quad$ : jumlah seluruh kata dalam dokumen pada kategori tertentu

$|x| \quad$ : jumlah total kata (distinc) di semua data latih

Tahap selanjutnya adalah mencari term (kata) dari dokumen yang belum diketahui ketegorinya (data uji) dengan pengetahuan pada data latih $P$ (wi/cj). Kemudian hitung probabilitas setiap dokumen $P(c j)$ yang telah disimpan dipengetahuan pada saat proses pelatihan sebelumnya, maka untuk setiap kategori dokumen dapat dihitung menggunakan Pers. (3).

$$
p\left(c_{j}\right) \prod_{i} p\left(w_{i} \mid c_{j}\right)
$$

Pers. (3)

untuk mencari nilai tersebut, kalikan nilai $p($ wi/cj) yang merupakan nilai kumulatif perkalian probabilitas kemunculan kata yang sama pada data latih dengan nilai probabilitas dokumen yang sesuai kategorinya $P(c j)$. Setelah didapatkan hasil perkalian pada masing-masing kategori dokumen, selanjutnya membandingkan dan mencari nilai probabilitas terbesar (CMAP) yang digunakan untuk klasifikasi data uji pada dokumen Jurnal PGSD yang akan diklasifikasikan ke dalam salah satu kategori yang tersedia (Schneider, 2005), perhitungan tersebut dapat dilihat pada Pers. (4).

$$
c_{M A P}=\operatorname{argmax}_{c_{j \in c}} p\left(c_{j}\right) \prod_{i} p\left(w_{i} \mid c_{j}\right)
$$

Pers. (4)

Alur dimulai dengan membaca data training, jika data numerik maka cari nilai mean dari setiap parameter, kemudian mencari standar deviasi. Sedangkan untuk mencari nilai dari probabilitas dengan menghitung jumlah data yang sesuai dari kategori yang sama dibagi dengan jumlah data (Bustami, 2014).

Keunggulan lain dari Naïve Bayes antara lain memberikan hasil baik pada aplikasi yang melakukan operasi real-word data (Bilski, 2011), waktu yang dibutukan untuk komputasi relative singkat, kinerja klasifikasi lebih baik dengan menghilangkan fitur yang tidak sesuai, dan performanya bagus (Handayani, 2015). Sedangkan kelemahannya membutuhkan jumlah record yang sangat banyak untuk mendapatkan hasil yang baik serta kurang akurat jika digunakan pada dataset yang tidak sesuai (Jadhav \& Channe, 2013). Algoritma Decision Tree J48 


\section{TEKNO Jumal Teknologi, Eektro, dan Kejurvan}

http://journal2.um.ac.id/index.php/tekno | ISSN 1693-8739

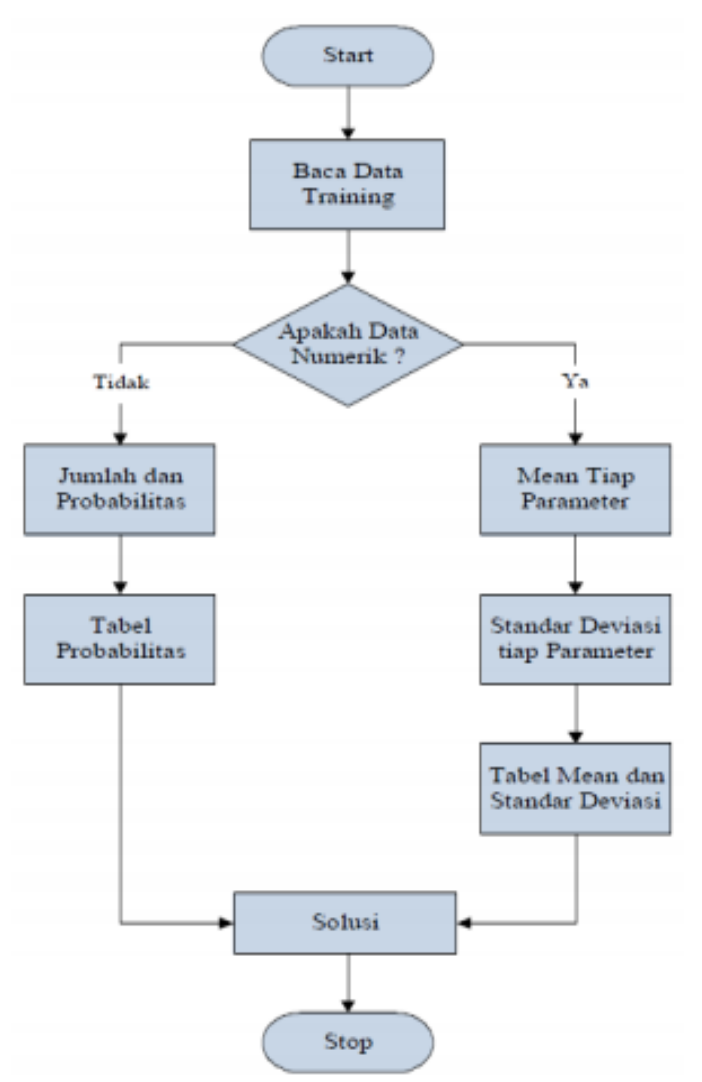

Gambar 1. Flowchart Naive Bayes

Algoritma berbasis Decision Tree $\mathrm{J} 48$ merupakan implementasi open source Java dari algoritma C4.5. Sehingga J48 memiliki cara yang sama dalam membangun pohon dengan algoritma C4.5. Algoritma pembelajaran yang mengimplementasikan pencarian heuristic menggunakan pohon keputusan. Diawali dengan memilih atribut sebagai akar, selanjutnya membuat cabang dari setiap nilai. Kemudian membagi setiap kasus pada cabang pohon, dan mengulangi proses ini sampai keseluruhan cabang memiliki kasus yang sama. Algoritma ini didasarkan pada hierarki pohon yang digunakan untuk membangun pohon klasifikasi yang mewakili struktur sederhana dengan nodus non-terminal menunjukkan tes atribut dan nodus terminal untuk menghasilkan hasil keputusan

Untuk menghitung gain dalam memilih atribut yang menjadi root Pers. (5), sedangkan untuk menghitung nilai entropy digunakan Pers. (6). 


\section{TEKNO Jumal Teknologi, Eektro, dan Kejuruan}

http://journal2.um.ac.id/index.php/tekno | ISSN 1693-8739

$$
\operatorname{Gain}(S, A)=\operatorname{Entropy}(S)-\sum_{i=1}^{n} \frac{\left|s_{i}\right|}{|s|} * \operatorname{Entropy}\left(s_{i}\right)
$$

\section{Keterangan:}

$S$ : himpunan kasus

$A$ : atribut

$n$ : jumlah partisi atribut $A$

$\left|S_{i}\right|$ : jumlah kasus pada partisi ke-i

$|S|$ : jumlah kasus dalam $S$

$$
\operatorname{Entropy}(S)=\sum_{i=1}^{n} p i * \log _{2} p i
$$

Keterangan:

$S$ : himpunan kasus

$A$ : fitur

$n$ : jumlah partisi $S$

pi : proporsi dari $S_{i}$ terhadap $S$

2. Dataset yang dgunakan

Dataset yang digunakan pada penelitian ini diambil dari journal.student.uny.ac.id/jurnal/baca/99 yang berisi data jurnal PGSD yang terdiri dari Volume dan tahun jurnal, Judul, dan Abstrak. Dataset merupakan data lama karena tahun diterbitkannya Jurnal PGSD tahun 2012 (Volume I) sampai tahun 2015 (Volume IV). Tenik pengambilan data dengan Crawling dari website resmi Universitas Negeri Yogyakarta.

Jumlah instance dari dataset jurnal PGSD berjumlah 200 data dengan 4 atribut ditampilkan pada Tabel 1.

\begin{tabular}{|c|c|c|c|}
\hline $\begin{array}{l}\text { Nama } \\
\text { atribut } \\
\text { Volume }\end{array}$ & \begin{tabular}{l}
\multicolumn{1}{c}{ Penjelasan } \\
\multicolumn{1}{c}{ Atribut } \\
Volume dan tahun jurnal \\
tersebut di terbitkan secara \\
resmi
\end{tabular} & $\begin{array}{r}\text { Tipe } \\
\text { data } \\
\text { String }\end{array}$ & $\begin{array}{l}\text { Rentang nilai / } \\
\text { enumerasi }\end{array}$ \\
\hline Judul & Judul dari jurnal PGSD UNY & String & kalimat \\
\hline Abstrak & $\begin{array}{l}\text { Berisi tentang penjabaran } \\
\text { secara singkat tentang jurnal }\end{array}$ & String & kalimat \\
\hline $\begin{array}{l}\text { Mata } \\
\text { Pelajaran }\end{array}$ & Atribut Kelas & nominal & $\begin{array}{l}\text { Agama dan Akhlak Mulia, } \\
\text { Kewarganegaraan dan Kepribadian, Ilmu } \\
\text { pengetahuan dan Teknologi, Estetika, } \\
\text { Jasmani, Olahraga dan Kesehatan }\end{array}$ \\
\hline
\end{tabular}

Tabel 1. Daftar Atribut Dalam Dataset 


\section{TEKNO Jumal Teknologi, Eektro, dan kejuruan}

http://journal2.um.ac.id/index.php/tekno | ISSN 1693-8739

Untuk memberi label pada dataset yang diambil, menggunakan Dasar Kurikulum Peraturan Pemerintah Nomor 19 Tahun 2005 tentang Standar Nasional Pendidikan pasal 6 ayat (1) menyatakan bahwa kurikulum untuk jenis pendidikan umum, kejuruan, dan khusus pada jenjang pendidikan dasar dan menengah.

Metadata pemberian label dan penjelasan dari datasets yang telah diubah dengan teknik string to words ditampilkan pada tabel 2.

Tabel 2. Daftar Label Dalam Dataset

\begin{tabular}{|c|c|c|c|}
\hline Label & $\begin{array}{l}\text { Penjelasan } \\
\text { Atribut }\end{array}$ & $\begin{array}{l}\text { Tipe } \\
\text { data }\end{array}$ & Rentang Nilai \\
\hline Agama dan Akhlak & $\begin{array}{l}\text { Cakupan yang merujuk pada } \\
\text { jenis mata pelajaran }\end{array}$ & Numeric & $0-100$ \\
\hline $\begin{array}{l}\text { Kewarganegaraan dan } \\
\text { Kepribadian }\end{array}$ & $\begin{array}{l}\text { Cakupan yang merujuk pada } \\
\text { jenis mata pelajaran }\end{array}$ & Numeric & $0-100$ \\
\hline $\begin{array}{l}\text { Ilmu Pengetahuan, dan } \\
\text { Teknologi }\end{array}$ & $\begin{array}{l}\text { Cakupan yang merujuk pada } \\
\text { jenis mata pelajaran }\end{array}$ & Numeric & $0-100$ \\
\hline Estetika & $\begin{array}{l}\text { Cakupan yang merujuk pada } \\
\text { jenis mata pelajaran }\end{array}$ & Numeric & $0-100$ \\
\hline $\begin{array}{l}\text { Jasmani Olahraga, dan } \\
\text { Kesehatan }\end{array}$ & $\begin{array}{l}\text { Cakupan yang merujuk pada } \\
\text { jenis mata pelajaran }\end{array}$ & Numeric & $0-100$ \\
\hline
\end{tabular}

Karakteristik dari dataset Jurnal PGSD yang digunakan dalam penelitin ini ditampilkan pada tabel 3.

Tabel 3. Karakteristik Dalam Dataset

\begin{tabular}{lcc}
\hline Nama Kelas & Jumlah instance & Presentase \\
\hline $\begin{array}{l}\text { Kelas "Agama dan Akhlak" } \\
\begin{array}{l}\text { Kelas "Kewarganegaraan } \\
\text { dan Kepribadian" }\end{array}\end{array}$ & 62 & $3 \%$ \\
$\begin{array}{l}\text { Kelas "Ilmu Pengetahuan } \\
\text { dan Teknologi" }\end{array}$ & 168 & $11 \%$ \\
Kelas "Estetika" & 4 & $2 \%$ \\
\hline
\end{tabular}

Pada Jurnal PGSD Universitas Negeri Yogyakarta tahun 2012 (Volume I) sampai tahun 2015 (Volume IV) tidak ada jurnal yang memuat cakupan yang merujuk mata pelajaran Jasmani, Olahraga dan Kesehatan. Sehingga peneliti tidak mencantumkan mata pelajaran tersebut dalam penelitian yang lebih lanjut.

3. Desain Eksperimen

WEKA adalah workbench untuk pembelajaran mesin dengan Bahasa pemrogram java. Aplikasi WEKA memungkinkan pengguna untuk mengidentifikasi informasi tersembunyi dari

TEKNO Vol. 29 Issue 1, p50-67| Jurusan Teknik Elektro, Universitas Negeri Malang, Indonesia | Maret 2019 U. Pujianto, Putri Yuni Ristanti | Perbandingan kinerja metode C4.5 dan Naive Bayes dalam klasifikasi ... 


\section{TEKNO Jumal Teknologi, Eektro, dan Kejiruan}

http://journal2.um.ac.id/index.php/tekno | ISSN 1693-8739

database dan sistem file dengan pilihan dan antarmuka visual yang mudah digunakan. Workbench Weka berisi koleksi alat visualisasi dan algoritma misalnya (C4.5 (C5), ID3, Kmeans, dan Apriori) untuk memecahkan masalah data mining dan prediksi secara real-world (Kulkarni \& Raj B. Kulkarni, 2016).

Klasifikasi adalah proses menemukan seperangkat model yang membahas dan membedakan ide dan kelas data, dengan tujuan untuk dapat menggunakan model tersebut untuk menebak kelas yang labelnya rahasia. Membangun model klasifikasi menggunakan data pelatihan. Model yang dihasilkan diuji dengan menugaskan label kelas ke kumpulan data objek data. Model diwakili sebagai pohon keputusan, aturan klasifikasi dan rumus matematika. Ini untuk mengklasifikasikan objek yang akan datang atau yang tidak diketahui. Tingkat ketepatan adalah persentase dari set pelatihan independen yaitu sampel uji yang diklasifikasikan dengan benar oleh model (Roshdi \& Roohparvar, 2015).

Dalam penelitian ini peniliti menggunakan WEKA untuk melakukan pengklasifikasin jurnal PGSD. WEKA yang digunakan yaitu WEKA 3.8.2 dengan menggunakan algoritma yang disediakan, yaitu Naive Bayes dan Decision Tree J48. Spesifikasi perangkat keras yang digunakan yaitu processor Core i3 dengan memory 4 GB.

\subsection{Langkah Penelitian}

a) Data set

Proses awal penelitian dimulai dengan pengambilan data pada website resmi Universitas Negeri Yogyakarta dengan Crawling menggunakan Octoparse, kemudian file tersebut di exsport menjadi file excel.

b) Pre processing

Tujuan pre processing adalah mengubah data yang sebelumnya tidak terstruktur menjadi data yang terstruktur Tahap pada pre processing terbagi dalam beberapa tahap. Tahap pertama yaitu case folding yaitu Menghilangkan semua tanda baca pada teks data untuk menghilangkan anomali data sehingga data dapat diproses pada weka. Dataset yang sebelumnya diolah dalam excel .csv diubah menjadi bentuk file .arff. Pilih filter StringToWordVector untuk mengubah tipe data menjadi tipe numeric dan nominal. Edit parameter pada StringToWordVector yaitu parameter lowerCaseTokens menjadi true (mengubah per kata pada teks menjadi kecil) dan mengubah parameter OutputWordCount menjadi true. Tahap kedua yaitu Tokenization yaitu memotong kalimat (teks panjang) pada teks menjadi per kata. dengan mengubah parameter.

Selanjutnya proses filtering untuk menghilangkan stopwords. Tahap terkahir yaitu stemming, yaitu teks yang telah melalui proses case folding yang bertujuan untuk 


\section{TEKNO Jumal Teknologi, Eektro, dan Kejurvan}

http://journal2.um.ac.id/index.php/tekno | ISSN 1693-8739

menghilangkan imbuhan menjadi kata dasar (root word). Selanjutnya pilih edit untuk mengubah menjadi set attribute as class.

c) Classifiication

Proses classification dilakukan dengan mengimport dataset bentuk .arff dalam weka, disini peneliti menggunakan 2 algoritma yaitu Naive Bayes dan Decisison Tree J48. Pada pengklasifikasian ini peneliti menggunakan Test Options Cross-Validations yaitu salah satu metode validasi (biasa disebut $k$-folds). Kinerja dari CrossValidations, dataset $A$ diacak menjadi bagian subset $A_{1}, A_{2}, A_{3}, A_{4}, \ldots \ldots, A_{k}$ yang disebut fold. Setiap folds (kotak hitam pada Gambar 2) digunakan sebagai data uji, sedangkan fold lainnya digunakan sebagai data pelatihan (Lukito \& Chrismanto, 2015).

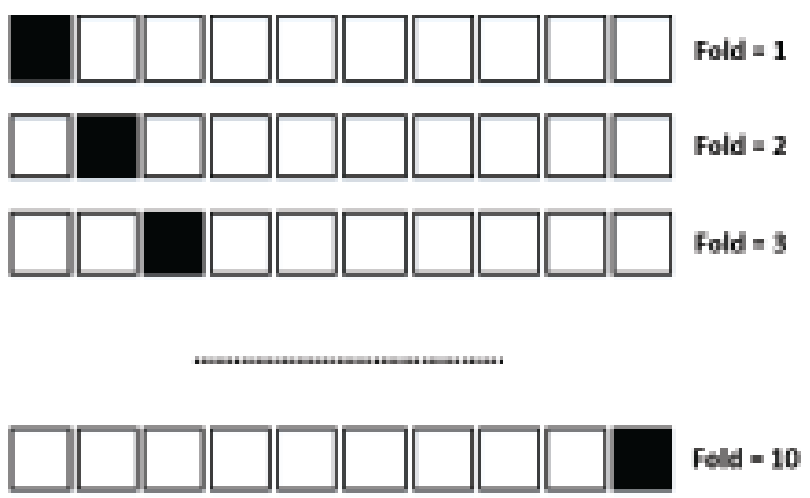

Gambar 2. Ilustrasi $k$-folds

d) Confusion Matrix

Tahap ini dilakukan uji ketepatan dengan confusion matrix kedua algoritma, yaitu menghitung accuracy, recall, precision dan error rate dengan Confusion Matrix ditampilkan pada tabel 4.

Tabel 4. Tabel Confusion Matrix

\begin{tabular}{lll}
\hline Kelas & Terklarifikasi Positif & Terklarifikasi Negatif \\
\hline Positif & TP (True Positive) & FN (False Negative) \\
Negatif & FP (False Positive) & TN (True Negative) \\
\hline
\end{tabular}

Pada kinerja Confusion Matrix dapat diukur dengan TP, FN, FP dan TN.

TP (True Positive) adalah jumlah data true yang yang memang memiliki nilai kebenaran true.

FN (False Negative) adalah jumlah data false yang memang memiliki nilai kebenaran false. 


\section{TEKNO Jumal Teknologi, Eektro, dan Kejurvan}

http://journal2.um.ac.id/index.php/tekno | ISSN 1693-8739

FP (False Negative) adalah jumlah data true yang dianggap sistem memiliki nilai kebenaran false.

TN (True Negative) adalah jumlah data false yang dinggap sistem memiliki nilai kebenaran true.

a) Menghitung keakuratan sistem mengklasifikasikan data dengan tepat.

$$
\text { Accuracy }=\frac{T P+T N}{T P+F N+F P+T N}
$$

b) Menghitung seberapa banyak nilai kebenaran (positive) dari dataset yang memang bernilai benar (positive) muncul.

$$
\text { TPRate }(\text { Recall })=\frac{T P}{T P+F N}
$$

c) Ketepatan nilai kebenaran dalam klasifikasi sesuai dengan nilai kebenaran yang sesungguhnya.

$$
\text { Precision }=\frac{T P}{T P+F P}
$$

e) Perbandingan Algoritma

Peneliti membandingkan kinerja algoritma Naive Bayes dan Decisison Tree J48 untuk mengetahui algoritma yang lebih baik untuk klasifikasi jurnal PGSD. Langkahlangkah penelitian dalam penelitian Information Retrieval ditunjukkan oleh gambar 3.

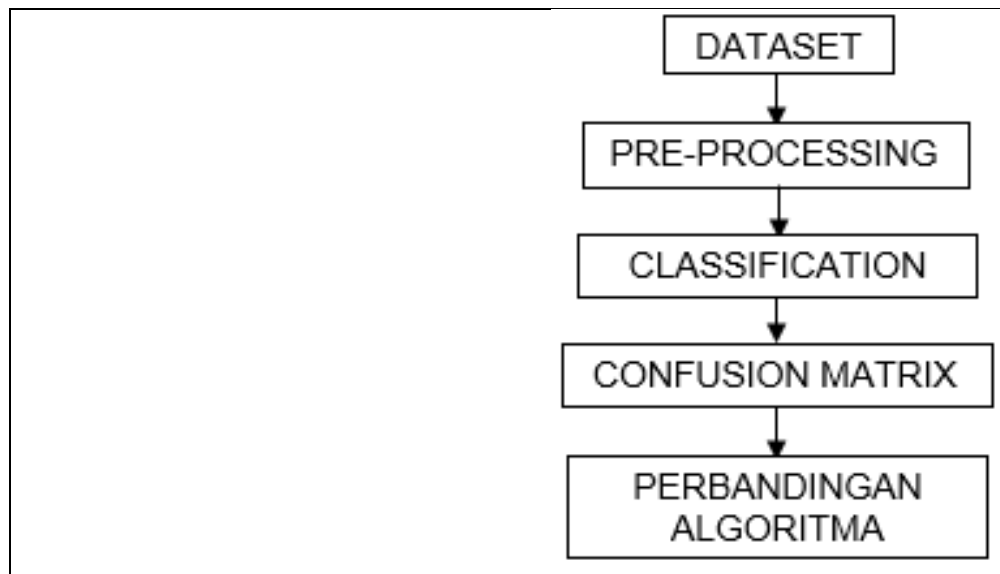

Gambar 3. Tahapan Penelitian 


\section{TEKNO Jumal Teknologi, Ekekro, dan Kejurvan}

http://journal2.um.ac.id/index.php/tekno | ISSN 1693-8739

\section{Hasil}

Berikut adalah hasil dari penelitian membandingkan algoritma Naive Bayes dan Decision Tree J48 pada Jurnal PGSD Universitas Negeri Yogyakarta dengan accuracy, presicion dan recall.

\section{a) Algorima Naive Bayes}

Hasil klasifikasi dataset jurnal PGSD dalam algoritma Naive bBayes dengan test options menggunakan Cross-validation dengan nilai folds 6 ditampilkan pada Tabel 5 .

Tabel 5. Hasil Pengujian Stratified Cross-validation

\begin{tabular}{lll}
\hline Stratified Cross-validation & & \\
\hline Summary & & \\
\hline Correctly Classified Instance & 168 & $16 \%$ \\
Incorrectly Classified Instance & 32 & \\
Kappa statistic & 0.4019 & \\
Mean absolute error & 0.08 & \\
Root mean squared error & 0.2828 & \\
Relative absolute error & $54.7831 \%$ \\
Root relative squared error & $106.6237 \%$ \\
Total Number of Instance & 200 \\
\hline
\end{tabular}

Untuk hasil dengan Confusion Matrix pada algoritma Naive Bayes ditampilkan pada Tabel 6.

Tabel 6. Hasil Confusion Matrix

\begin{tabular}{ccccl}
\hline $\begin{array}{c}\text { Agama dan } \\
\text { akhlak mulia }\end{array}$ & $\begin{array}{c}\text { Kewarganegaraan } \\
\text { dan Kepribadian }\end{array}$ & $\begin{array}{c}\text { Ilmu Pengetahuan } \\
\text { dan teknologi }\end{array}$ & Estetika & Classified as \\
\hline 1 & 4 & 1 & 0 & Agama dan akhlak mulia \\
2 & 10 & 10 & 0 & $\begin{array}{l}\text { Kewarganegaraan dan } \\
\text { Kepribadian }\end{array}$ \\
0 & 10 & 157 & 1 & Ilmu Pengetahuan dan teknologi \\
0 & 1 & 3 & 0 & Estetika \\
\hline
\end{tabular}

Keterangan:

a) Pada baris pertama nilai "1 4 1 0 " menunjukkan bahwa instance class Agama dan akhlak mulia dalam data set JurnalPGSD, 5 salah diklasifikasikan sebagai Kewarganegaraan dan Kepribadian, dan 1 salah diklasifikasikan IImu Pengetahuan dan Teknologi.

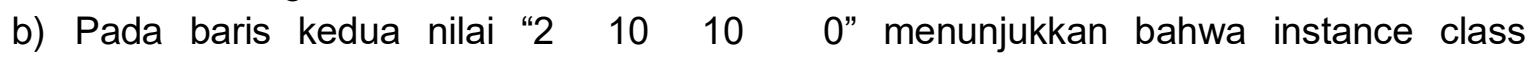
Kewarganegaraan dan Kepribadian dalam data set JurnalPGSD, 2 salah diklasifikasikan sebagai Agama dan akhlak mulia, dan 10 salah diklasifikasikan IImu Pengetahuan dan Teknologi.

c) Pada baris ketiga nilai "0 10157 1" menunjukkan bahwa instance class IImu Pengetahuan dan Teknologi dalam data set JurnalPGSD, 10 salah diklasifikasikan sebagai Kewarganegaraan dan Kepribadian, dan 1 salah diklasifikasikan Estetika. 


\section{TEKNO Jumal Teknologi, Eektro, dan Kejurvan}

http://journal2.um.ac.id/index.php/tekno | ISSN 1693-8739

d) Pada baris keempat nilai "0 13 0" menunjukkan bahwa instance class Estetika dalam data set JurnaIPGSD, 1 salah diklasifikasikan sebagai Kewarganegaraan dan Kepribadian ,dan 3 salah diklasifikasikan sebagai Ilmu pengetahuan dan Teknologi.

Untuk hasil Accuracy pada algoritma Naive Bayes sebagai berikut:

$$
\text { accuracy }=\frac{1+10+157+0}{200} 100 \%=84 \%
$$

Untuk hasil Recall pada algoritma Naive Bayes sebagai berikut:
a) Agama dan akhlak mulia $=\frac{1}{1+(4+1+0)}=0,167$
b) Kewarganegaraan dan Kepribadian $=\frac{10}{10+(2+10+0)}=0,455$
c) IImu Pengetahuan dan teknologi $=\frac{157}{157+(0+10+1)}=0,935$
d) Estetika $=\frac{0}{0+(0+1+3)}=0$

Nilai rata-rata Recall $84 \%$

Untuk hasil Presicion pada algoritma Naive Bayes sebagai berikut:
a) Agama dan akhlak mulia $=\frac{1}{1+(2+0+0)}=0,333$
b) Kewarganegaraan dan Kepribadian $=\frac{10}{10+(4+10+1)}=0,400$
c) IImu Pengetahuan dan teknologi $=\frac{157}{157+(1+10+3)}=0,918$
d) Estetika $=\frac{0}{0+(0+1+0)}=0$

Nilai rata-rata Precision $82,5 \%$

\section{Naive Bayes}

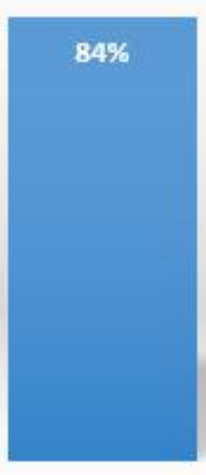

accuracy

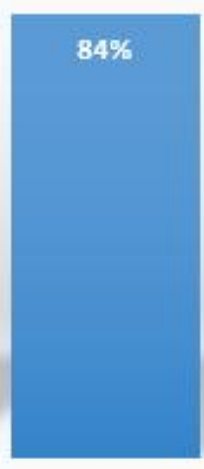

recall

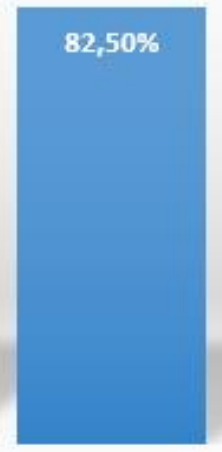

precision

\section{$16 \%$}

error rate

Gambar 4. Parameter Kinerja Algoritma Naïve Bayes 


\section{TEKNO Jumal Teknologi, Eektro, dan kejiruan}

http://journal2.um.ac.id/index.php/tekno | ISSN 1693-8739

Hasil Detailed Accuracy Algoritma Naive Bayes pada Weka ditampilkan pada Tabel .

Tabel 7. Detailed Accuracy Naive Bayes

\begin{tabular}{llllll}
\hline Parameter & $\begin{array}{l}\text { Agama dan } \\
\text { akhlak mulia }\end{array}$ & $\begin{array}{l}\text { Kewarganegaraan } \\
\text { dan Kepribadian }\end{array}$ & $\begin{array}{l}\text { Ilmu Pengetahuan } \\
\text { dan teknologi }\end{array}$ & Estetika & $\begin{array}{l}\text { Weighted } \\
\text { Avg }\end{array}$ \\
\hline TP Rate & 0,167 & 0,455 & 0,935 & 0,000 & 0,840 \\
FP Rate & 0,010 & 0,084 & 0,438 & 0,005 & 0,377 \\
Precision & 0,333 & 0,400 & 0,918 & 0,000 & 0,825 \\
Recal & 0,167 & 0,455 & 0,935 & 0,000 & 0,840 \\
F-Measure & 0,222 & 0,426 & 0,926 & 0,000 & 0,832 \\
MCC & 0,219 & 0,350 & 0,517 & $-0,010$ & 0,480 \\
ROC Area & 0,724 & 0,782 & 0,776 & 0,480 & 0,769 \\
PRC Area & 0,221 & 0,309 & 0,925 & 0,020 & 0,818 \\
\hline
\end{tabular}

\section{b) Algoritma Decisison Tree J48}

Hasil klasifikasi dataset jurnal PGSD dalam algoritma naive bayes dengan test options menggunakan Cross-validation dengan nilai folds 6 ditampilkan pada Tabel 8 .

Tabel 8. Hasil Pengujian Stratified Cross-validation

\begin{tabular}{lll}
\hline Stratified Cross-validation & & \\
\hline Summary & & \\
\hline Correctly Classified Instance & 174 & $87 \%$ \\
Incorrectly Classified Instance & 26 & $13 \%$ \\
Kappa statistic & 0.4488 & \\
Mean absolute error & 0.0831 & \\
Root mean squared error & 0.2469 & \\
Relative absolute error & $56.8742 \%$ & \\
Root relative squared error & $93.065 \%$ \\
Total Number of Instance & 200 & \\
\hline
\end{tabular}

Untuk hasil dengan Confusion Matrix pada algoritma Naive Bayes ditampilkan pada Tabel 9.

Tabel 9. Hasil Confusion Matrix

\begin{tabular}{ccccl}
\hline $\begin{array}{c}\text { Agama dan } \\
\text { akhlak mulia }\end{array}$ & $\begin{array}{c}\text { Kewarganegaraan } \\
\text { dan Kepribadian }\end{array}$ & $\begin{array}{c}\text { Ilmu Pengetahuan } \\
\text { dan teknologi }\end{array}$ & Estetika & Classified as \\
\hline 4 & 0 & 2 & 0 & Agama dan akhlak mulia \\
2 & 7 & 13 & 0 & $\begin{array}{l}\text { Kewarganegaraan dan } \\
\text { Kepribadian }\end{array}$ \\
0 & 4 & 163 & 1 & Ilmu Pengetahuan dan teknologi \\
0 & 1 & 2 & 0 & Estetika \\
\hline
\end{tabular}

TEKNO Vol. 29 Issue 1, p50-67| Jurusan Teknik Elektro, Universitas Negeri Malang, Indonesia | Maret 2019

U. Pujianto, Putri Yuni Ristanti | Perbandingan kinerja metode C4.5 dan Naive Bayes dalam klasifikasi ... 


\section{TEKNO Jumal Teknologi, Eektro, dan Kejivuan}

http://journal2.um.ac.id/index.php/tekno | ISSN 1693-8739

Keterangan:

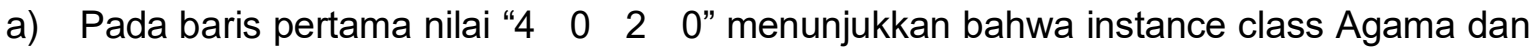
akhlak mulia dalam data set JurnaIPGSD, 2 salah diklasifikasikan sebagai IImu Pengetahuan dan teknologi

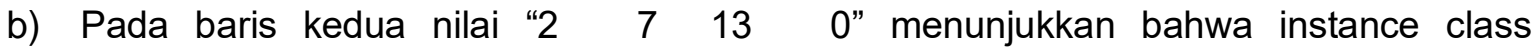
Kewarganegaraan dan Kepribadian dalam data set JurnalPGSD, 2 salah diklasifikasikan sebagai Agama dan akhlak mulia, 13 salah diklasifikasikan IImu Pengetahuan dan Teknologi.

c) Pada baris ketiga nilai "0 4163 1" menunjukkan bahwa instance class IImu Pengetahuan dan Teknologi dalam data set JurnalPGSD, 4 salah diklasifikasikan sebagai Kewarganegaraan dan Kepribadian, dan 1 salah diklasifikasikan Estetika.

d) Pada baris keempat nilai "0 22 0" menunjukkan bahwa instance class Estetika dalam data set JurnaIPGSD, 2 salah diklasifikasikan sebagai Kewarganegaraan dan Kepribadian, dan 2 salah diklasifikasikan sebagai Ilmu Pengetahuan dan teknologi.

Untuk hasil Accuracy pada algoritma Decision Tree J48 sebagai berikut:

$$
\text { accuracy }=\frac{4+7+163+0}{200} 100 \%=86 \%
$$

Untuk hasil Recall pada algoritma Decision Tree J48 sebagai berikut:
a) Agama dan akhlak mulia $=\frac{4}{4+(0+2+0)}=0,667$
b) Kewarganegaraan dan Kepribadian $=\frac{7}{7+(2+13+0)}=0,318$
c) IImu Pengetahuan dan teknologi $=\frac{163}{163+(0+4+1)}=0,970$
d) Estetika $=\frac{0}{0+(0+1+2)}=0$

Nilai rata-rata $R e c a l l 87 \%$

Untuk hasil Presicion pada algoritma Decision Tree J48 sebagai berikut:
a) Agama dan akhlak mulia $=\frac{4}{4+(2+0+0)}=0,667$
b) Kewarganegaraan dan Kepribadian $=\frac{7}{7+(0+4+1)}=0,538$
c) IImu Pengetahuan dan teknologi $=\frac{163}{163+(2+13+2)}=0.906$
d) Estetika $=\frac{0}{0+(0+0+1)}=0$
Nilai rata-rata Precision $84 \%$ 


\section{TEKNO Jumal Teknologi, Eektro, dan Kejuruan}

http://journal2.um.ac.id/index.php/tekno | ISSN 1693-8739

\section{Decision Tree $\mathbf{5 4 8}$}

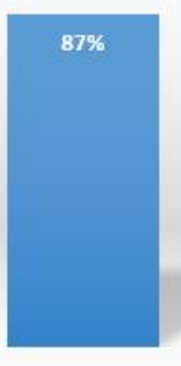

accuracy

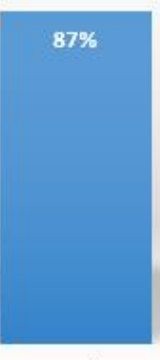

recall

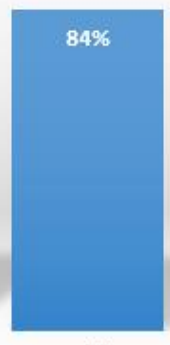

precision

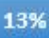

error rate

Gambar 5. Parameter Kinerja Algoritma Decsion Tree J48

Hasil Detailed Accuracy Algoritma Naive Bayes pada Weka ditampilkan pada Tabel 10.

Tabel 10. Hasil Confusion Matrix

\begin{tabular}{lccccc}
\hline Parameter & $\begin{array}{l}\text { Agama dan } \\
\text { akhlak } \\
\text { mulia }\end{array}$ & $\begin{array}{l}\text { Kewarganegaraan } \\
\text { dan Kepribadian }\end{array}$ & $\begin{array}{l}\text { Ilmu Pengetahuan } \\
\text { dan teknologi }\end{array}$ & Estetika & $\begin{array}{l}\text { Weighted } \\
\text { Avg }\end{array}$ \\
\hline TP Rate & 0,667 & 0,318 & 0,970 & 0,000 & 0,870 \\
FP Rate & 0,010 & 0,034 & 0,531 & 0,005 & 0,450 \\
Precision & 0,667 & 0,538 & 0,906 & 0,000 & 0,840 \\
Recall & 0,667 & 0,318 & 0,970 & 0,000 & 0,870 \\
F-Measure & 0,667 & 0,400 & 0,937 & 0,000 & 0,851 \\
MCC & 0,656 & 0,361 & 0,536 & $-0,010$ & 0,510 \\
ROC Area & 0,747 & 0,661 & 0,745 & 0,480 & 0,724 \\
PRC Area & 0,622 & 0,300 & 0,910 & 0,020 & 0,817 \\
\hline
\end{tabular}

\section{c) Perbandingan Algoritma Naïve Bayes dan Decision Tree J48}

Setelah melakukan penelitian dalam mengklasifikasikan dataset dengan menggunakan algoritma naïve bayes dan Decision Tree J48, hasil pengujian berdasarkan accuracy, recall, persicion, dan error rate ditampilkan pada Tabel 11.

Tabel 11. Hasil Confusion Matrix

\begin{tabular}{llc}
\hline \multicolumn{1}{c}{ Perbandingan } & \multicolumn{2}{c}{ Algoritma } \\
& Naive Bayes & Decision Tree J48 \\
\hline accuracy & $84 \%$ & $87 \%$ \\
recall & $84 \%$ & $87 \%$ \\
precision & $82 \%$ & $84 \%$ \\
Error Rate & $16 \%$ & $13 \%$ \\
\hline
\end{tabular}

TEKNO Vol. 29 Issue 1, p50-67| Jurusan Teknik Elektro, Universitas Negeri Malang, Indonesia | Maret 2019 U. Pujianto, Putri Yuni Ristanti | Perbandingan kinerja metode C4.5 dan Naive Bayes dalam klasifikasi ... 


\section{TEKNO Jumal Teknologi, Eektro, dan kejuruan}

http://journal2.um.ac.id/index.php/tekno | ISSN 1693-8739 Berikut grafik perbandingan kinerja kedua algoritma berdasarkan accuracy, recall, precision, dan error rate
ditampilkan pada Gambar 9

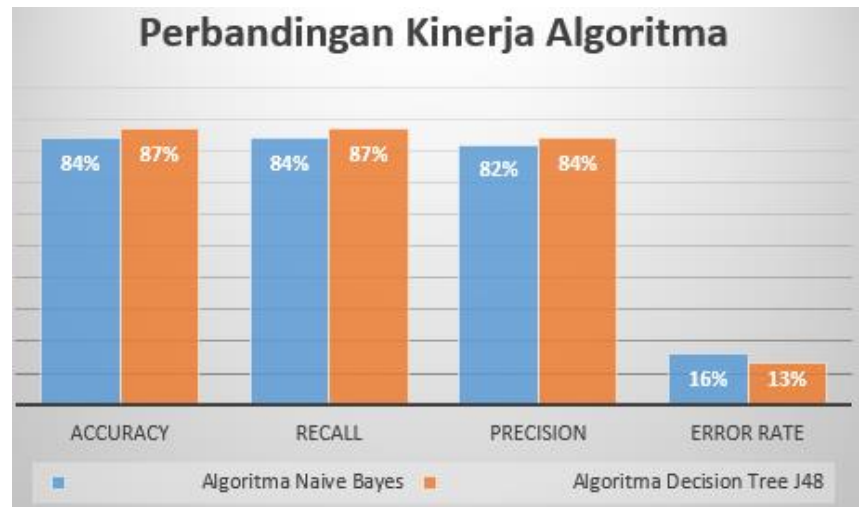

Gambar 9. Parameter Kinerja Kedua Algoritma

\section{Kesimpulan}

Berdasarkan uraian hasil penelitian, maka dapat dikemukakan kesimpulan sebagai berikut:

- Berdasarkan hasil penelitian klasifikasi Jurnal PGSD dengan menggunakan algortima naive bayes dan algoritma Decisison Tree J48, hasil accuracy dari kedua algoritma tersebut menunjukan tingkat accuracy Decision Tree J48 sebesar $87 \%$ lebih baik dari pada algoritma Naive Bayes sebesar $84 \%$.

- Algoritma Decision Tree J48 juga memberikan nilai pada recall dan precision sebesar $87 \%$ dan $84 \%$ lebih baik dibandingkan algoritma Naive Bayes dengan nilai $82 \%$ dan $83 \%$.

- Dengan hasil parameter pengujian mengunakn confussion matrik, peneliti merekomendasikan penggunaan algoritma Decision Tree J48 pada klasifikasi Jurnal PGSD. Hasil accuracy akan menunjukan hasil berbeda tergantung dengan jenis data, nilai folds dan jumlah instance, label class.

\section{Daftar Rujukan}

Ashari, A., Paryudi, I., \& Tjoa, A. (2013). Performance Comparison between Naïve Bayes, Decision Tree and k-Nearest Neighbor in Searching Alternative Design in an Energy Simulation Tool. International Journal of Advanced Computer Science and Applications, 4(11), 33-39. https://doi.org/10.14569/IJACSA.2013.041105

Bilski, A. (2011). A review of artificial intelligence algorithms in document classification. 


\section{TEKNO Jurnal Teknologi, Elektro, dan Kejuruan}

http://journal2.um.ac.id/index.php/tekno | ISSN 1693-8739

International Journal of Electronics and Telecommunications, 57(3), 263-270. https://doi.org/10.2478/v10177-011-0035-6

Bustami. (2014). Penerapan Algoritma Naive Bayes. Jurnal Informatika, 8(1), 884-898.

Handayani, F. dan F. S. P. (2015). Implementasi Algoritma Naive Bayes Classifier dalam Pengklasifikasian Teks Otomatis Pengaduan dan Pelaporan Masyarakat melalui Layanan Call Center 110, 7(1).

Huang, F., Zhu, Q., Zhou, J., Tao, J., Zhou, X., Jin, D., ... Wang, L. (2017). Research on the parallelization of the DBSCAN clustering algorithm for spatial data mining based on the Spark platform. Remote Sensing, 9(12). https://doi.org/10.3390/rs9121301

lqbal, M., Abid, M. M., Waheed, U., \& Kazmi, S. H. A. (2017). Classification of Malicious Web Pages through a J48 Decision Tree, a Naïve Bayes, a RBF Network and a Random Forest Classifier for WebSpam Detection. International Journal of $U$ - and E-Service, Science and Technology, 10(4), 51-72. https://doi.org/10.14257/ijunesst.2017.10.4.05

Jadhav, S. D., \& Channe, H. P. (2013). Comparative Study of K-NN, Naive Bayes and Decision Tree Classification Techniques. International Journal of Science and Research (IJSR), 14611(1), 2319-7064. Retrieved from www.ijsr.net

Karthika, S., \& Sairam, N. (2015). A Naïve Bayesian Classifier for Educational Qualification. Indian Journal of Science and Technology, 8(16). https://doi.org/10.17485/ijst/2015/v8i16/62055

Kulkarni, E. G., \& Raj B. Kulkarni. (2016). WEKA Powerful Tool in Data Mining. International Journal of Computer Applications, 975 - 888(8887), 10-15.

Lukito, Y., \& Chrismanto, A. R. (2015). Perbandingan Metode-Metode Klasifikasi Perbandingan Metode - Metode Klasifikasi Untuk Indoor Positioning System. Jurnal Teknik Informatika Dan Sistem Informasi (JuTISI), 1(AUGUST 2015), 123-131. Retrieved from http://jutisi.maranatha.edu/index.php/jutisi/article/download/373/368

Rajeswari, R. P., \& Juliet, K. (2017). Text Classification for Student Data Set using Naive Bayes Classifier and KNN Classifier. International Journal of Computer Trends and Technology, 43(1), 8-12.

Roshdi, A., \& Roohparvar, A. (2015). Review : Information Retrieval Techniques and Applications. International Journal of Computer Networks and Communications Security, 3(9), 373-377.

Schneider, K.-M. (2005). Techniques for Improving the Performance of Naive Bayes for Text Classification. Computational Linguistics and Intelligent Text Processing, (i), 682-693. https://doi.org/10.1007/978-3-540-30586-6_76 


\section{TEKNO Jurnal Teknologi, Elektro, dan Kejuruan}

http://journal2.um.ac.id/index.php/tekno | ISSN 1693-8739

Song, J. H., \& Woo, H. Y. (2015). A study on AQ (adversity quotient), job satisfaction and turnover intention according to work units of clinical nursing staffs in Korea. Indian Journal of Science and Technology, 8(November), 74-78. https://doi.org/10.17485/ijst/2015/v8i

Suyadi, S., Setyanto, A., \& Fattah, H. Al. (2017). Analisis Perbandingan Algoritma Decision Tree (C4.5) Dan K-Naive Bayes Untuk Mengklasifikasi Penerimaan Mahasiswa Baru Tingkat Universitas. Indonesian Journal of Applied Informatics, 2(1), 59.

https://doi.org/10.20961/ijai.v2i1.13258

Wahyuningtyas, R. S., Pratiwi, H. S., Studi, P., Informatika, T., Teknik, F., \& Tanjungpura, U. (2015). Sistem Pakar Penentuan Jenis Kulit Wajah Wanita Menggunakan Metode Naïve Bayes, 1(1). 